\title{
Caroticoclinoid Foramen in Human Skulls: Incidence, Morphometry and its Clinical Implications
}

\author{
Foramen Caróticoclinoideo en Cráneos Humanos: \\ Incidencia, Morfometría y sus Implicaciones Clínicas
}

\author{
*Alexandre Rodrigues Freire; "Ana Cláudia Rossi; "Felippe Bevilacqua Prado; \\ ***Francisco Carlos Groppo; "Paulo Henrique Ferreira Caria \& ${ }^{* * *}$ Paulo Roberto Botacin
}

FREIRE, A. R.; ROSSI, A. C.; PRADO, F. B.; GROPPO, F. C.; CARIA, P. H. F. \& BOTACIN, P. R. Caroticoclinoid foramen in human skulls: incidence, morphometry and its clinical implications. Int. J. Morphol., 29(2):427-431, 2011.

SUMMARY: The caroticoclinoid foramen is an inconstant structure, formed by the union of the anterior and middle clinoid processes. The aim of this study was to perform an incidence and morphometry of the caroticoclinoid foramen in Brazilian human skulls and discuss its clinical implications. Eighty dry human skulls with sex distinction were used, and 3 groups of incidence were determined: General, sex, and sides. The morphometry was performed using a manual caliper and the major diameter of the foramina was measured; the values were also divided in general, according to sex and sides. The incidence of skulls with at least one foramen was $8.5 \%$. According to the sides, $8.5 \%$ of the skulls showed foramen on the right side and $2.5 \%$ on the left. We found $2.5 \%$ of the skulls with bilateral foramen and $6.25 \%$ with unilateral foramen. In relation to sex, the foramens were found in 5\% of male skulls and $12.5 \%$ of female skulls. The major diameter of this structure presented on mean, values of $5.23 \mathrm{~mm}$ on general, $5.18 \mathrm{~mm}$ on the right side and $5.35 \mathrm{~mm}$ on the left, $5.30 \mathrm{~mm}$ in male skulls and $5.18 \mathrm{~mm}$ in female skulls. The anatomical characteristics of this foramen should be considered in view of its clinical implications associated with neurosurgery as clinoid process removal, and symptoms as headache due to internal carotid artery alterations in this region. In conclusion knowledge of this structure supports the diagnosis and treatment of clinical complications related to this variation.

KEY WORDS: Foramen; Morphometry; Carotid artery; Cranial fossa; Middle.

\section{INTRODUCTION}

The caroticoclinoid foramen $(\mathrm{CCF})$ is an inconstant structure which is located in the middle cranial fossa, composed by the ossification of a fibrous ligament (Sicher \& $\mathrm{Du}$ Brul, 1977) that begins on the anterior clinoid process and joins to the medium clinoid process (Erturk et al., 2004). CCF allows the passage of one of six segments of the internal carotid artery (ICA), the clinoidal segment (Erturk et al.; Sicher \& Du Brul).

Severals authors studied the anatomical characteristics of CCF in different populations (Dodo \& Ishida, 1987; Lee et al., 1997; Reisch et al., 2002; Ozdog ־mus, et al., 2003). Moreover, due to its location on the skull, these characteristics associate to clinical implications, which are considered of great interest for neuroanatomy and neurosurgery (Seoane $e t$ al., 1998; Erturk et al.; Gupta et al., 2005; Das et al., 2007).
The aim of this study was to evaluate the incidence of skulls with the CCF as well as perform its morphometry and discuss the clinical influences that this structure can generate.

\section{MATERIAL AND METHOD}

We used 80 adult dried human skulls with sex distinction (40 males and 40 females) belonging to Department of Basic Sciences of Faculty of Dentistry of Araçatuba, SP, Brazil - UNESP. To select the skulls the integrity of the clinoid process was evaluated. Those with damaged clinoid process were excluded from the sample.

The incidence of skulls with CCF was evaluated

\footnotetext{
Department of Morphology, Anatomy Area, State University of Campinas - UNICAMP, Piracicaba, São Paulo, Brazil.

** Department of Physiological Sciences, Pharmacology/Anesthesiology/Therapeutics Area, State University of Campinas - UNICAMP, Piracicaba, São Paulo, Brazil.

**** Department of Basic Sciences, Anatomy Area, Paulista State University - UNESP, Araçatuba, São Paulo, Brazil.
} 
according to description by Erturk et al (2004): skulls with the presence of at least $1 \mathrm{CCF}$ with complete ossification of the fibrous ligament (complete formation of the foramen) (Fig. 1), regardless of side and sex; skulls with the presence of the CCF on the right and on the left side; skulls with the presence of the CCF on both sides (bilateral) and on one side (unilateral). This study also evaluated the incidence according to sex.

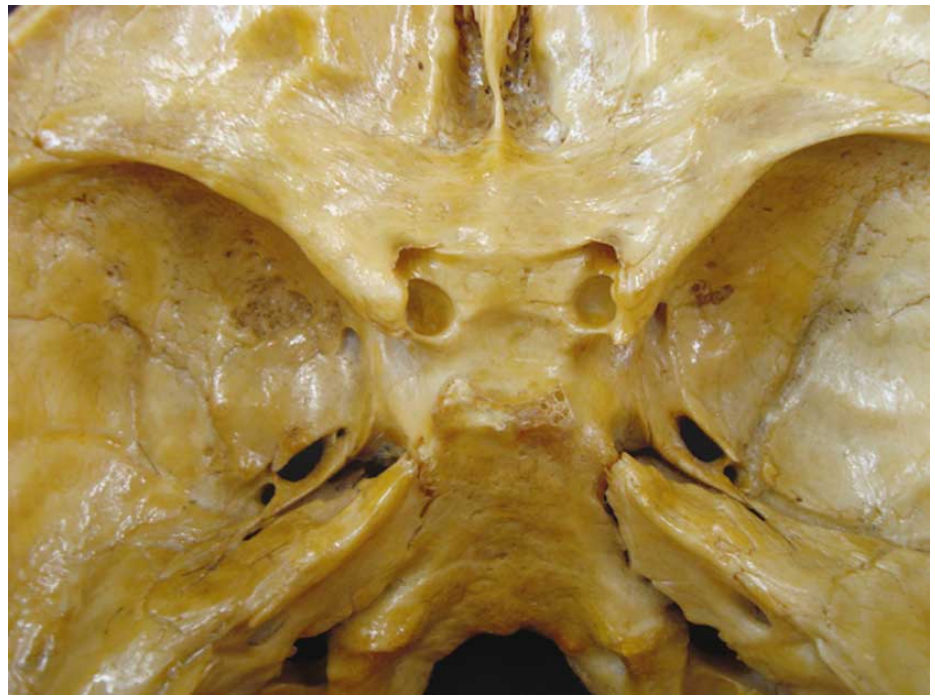

Fig. 1. The internal view of the skull shows the caroticoclinoid foramen bilaterally.

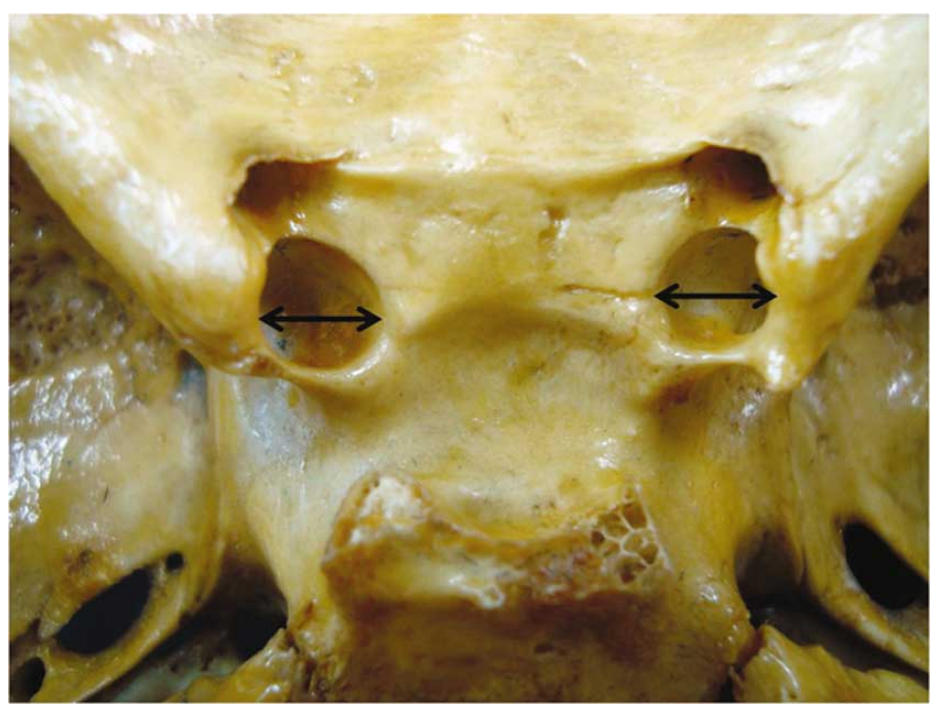

Fig. 2. Internal view of the skull. The double-headed arrow indicates the diameter measured in the morphometry.

The morphometry was performed using a manual caliper and measuring the major diameter of each foramen (Fig. 2). To avoid errors, the measurement was performed 3 times by the same examiner considering the repeated values. These values were obtained in millimeters $(\mathrm{mm})$. After obtaining the results, statistical analysis was performed through the Fisher exact test for analysis of distribution of the foramen according to sex.

\section{RESULTS}

In the analysis it was observed that the $\mathrm{CCF}$ is situated on the middle cranial fossa and is constituted of 80 dry skulls showing: 7 skulls $(8.5 \%)$ with at least one CCF regardless of side and sex (table I); 02 skulls with bilateral presence and 05 unilateral of the $\mathrm{CCF}$, resulting incidences of $2.5 \%$ and $6.25 \%$, respectively (table I). According with the sides, major presence on the right side ( 7 foramens) compared to the left ( 2 foramens) was observed, incidences of $8.5 \%$ and $2.5 \%$, respectively (table I). According to sex, 5 male skulls and 2 female skulls showed the CCF, incidences of $7.5 \%$ and $5 \%$, respectively (Table I).

Table I. Incidence of at least one foramen in the total skulls $(\mathrm{n}=80)$ evaluated, according to sides (left, right, uni and bilaterally) and according to sex (male and female, $n=40$ ). Also shows the values of morphometry of the foramens (millimeters).

\begin{tabular}{lcc}
\hline & Incidence & Mean diameter $-\mathrm{mm}$ \\
\hline Total & 8.5 & $5.23( \pm 3.90)$ \\
Right & 8.5 & $5.18( \pm 4.66)$ \\
Left & 2.5 & $5.35( \pm 0.71)$ \\
Unilateral & 6.5 & - \\
Bilateral & 2.5 & - \\
Male & 7.5 & $5.30( \pm 3.61)$ \\
Female & 5 & $5.18( \pm 4.57)$ \\
\hline
\end{tabular}

The mean $( \pm$ SD) diameter of the foramen, regardless of side or sex, was $5.23 \mathrm{~mm}( \pm 3.9)$ (Table I). The major diameter found in this structure was on mean, $5.18 \mathrm{~mm}( \pm 4.66)$ on the right side and $5.35 \mathrm{~mm}( \pm$ $0.71)$ on the left; mean values of $5.30 \mathrm{~mm}( \pm 3.61)$ in the male skulls and $5.18 \mathrm{~mm}( \pm 4.57)$ in the female skulls were found.

The data revealed that there was no statistically significant difference in the Fisher's exact test ( $p>$ 0.05 ) between the distributions of the CCF according to sex, regarding the side examined (Table II). It was observed that 2 female skulls showed the foramens bilaterally, while 3 male skulls showed the foramens only on the right side (Table II). Thus, when the foramen is observed, there is $71.5 \%$ probability on the right side and $28.5 \%$ on the left. 
Table II. Distribution of the foramen according to sex, regarding the sides examined. Note the absence of the foramen on the left side in male skulls.

\begin{tabular}{lcc}
\hline & \multicolumn{2}{c}{ Sex } \\
Sides & Female & Male \\
\hline Right & $2(5 \%)$ & $3(7.5 \%)$ \\
Left & $2(5 \%)$ & 0 \\
Absent & $38(95 \%)$ & $37(92.5 \%)$ \\
\hline
\end{tabular}

\section{DISCUSSION}

The ossification of fibrous ligaments is considered a normal physiological process that occurs with age (Erturk et al.). However this process is an exception when one considers the formation of the CCF (Donald, 1998; Ozdogmus et al.; Standring, 2005). Moreover, the study by Hochstetter (1940) and Kier (1966) revealed the presence of this foramen in fetuses and children skulls.

The incidence of the CCF was significantly lower (8.5\%) compared to other studies as of Erturk et al. (2004) (35.67\%), when the presence of at least one foramen in the skull was analyzed. According to the sides, this study resulted in a lower incidence ( 7 sides on the right side and 2 on the left) compared to other studies such as Ozdogmus et al. that evaluated 50 autopsies of human in a Turkish population with the presence of fully ossified ligaments (27 sides) and in their study confirmed the presence of fibrous ligament partially ossified in 55 sides (26 on the right side and 29 on the left). Gupta et al. observed 14 sides with the foramen of a total of 70 skulls ( $20 \%$ incidence).

The foramens analyzed had mean diameter of 5.23 $\mathrm{mm}( \pm 3.9)$ regardless of sex or side, similar to results reported by Ozdogmus et al., who performed measurements of the CCF in 50 autopsies of human (mean of $5.14 \mathrm{~mm}$ on the right side and $5.25 \mathrm{~mm}$ on the left) and in these values, there was no statistically significant difference when comparing sex.

Erturk et al. measured the diameter of the distal area of ICA, in its clinoid segment, and found mean diameter of $5.24 \mathrm{~mm}$ on the right side and $5.25 \mathrm{~mm}$ on the left, diameters larger than the CCF. The present study and Erturk et. al. performed measurements of the diameter of CCF in order to report that the presence of this foramen may cause compression of the ICA. Therefore, the study of Ozdogmus et al. demonstrated that due to caliber of the ICA in this area of the skull being larger than diameter of
$\mathrm{CCF}$, it was reported that there is a high possibility to induce a headache caused by compression of the ICA in the presence of CCF. This feature is crucial for the choice of surgical removal of the anterior clinoid process (Ozdogmus et al.).

Changes in internal carotid artery may cause compression of the cavernous sinus due to its medial position (Narolewski, 2003; Gupta et al.). The study of Das et al. showed that the presence of the CCF cause morphological changes in the internal carotid artery in almost all cases.

In clinical practice, when a paraclinoid aneurysm occurs, the anterior clinoid process is removed as treatment for this disease (Dolenc, 1985; Inoue et al., 1990). This treatment is more difficult when the CCF is present, causing higher possibility of serious bleeding in this region (Narolewski).

After removal the anterior clinoid process, a space is observed: the clinoid space, which have triangular form and small size (Gupta et al.). This space varies according to dimension of anterior clinoid process and the internal carotid artery (Sekhar \& Akin, 1987). Furthermore, Sekhar \& Akin showed the position of the CCF in an area close to the cavernous sinus. The formation of the CCF may change the dimensions of this area (Sekhar \& Akin), considered by some authors as intracavernous (Dolenc; Seoane et al.). Other authors consider it as outside of the cavernous sinus (Kobayashi et al., 1989).

In conclusion, the incidence of the CCF in Brazilian skulls is low, as well as reported in different populations by other studies. The literature showed that the formation of the CCF may cause alterations in the ICA, especially on the clinoid segment, when comparing the transversal diameter of these structures. The presence of this foramen has an important clinical implication as the possible cause of headache symptom and surgical procedures as the removal of the clinoid process. Therefore, the knowledge of this structure supports the diagnosis and treatments of clinical complications related to this anatomical variation.

\section{ACKNOWLEDGMENTS}

Special thanks to lab technician José Ari Gualberto Junqueira, Laboratory of Anatomy, Faculty of Dentistry of Araçatuba, SP, Brazil - UNESP for having made available the skulls used in this study. 
FREIRE, A. R.; ROSSI, A. C.; PRADO, F. B.; GROPPO, F. C.;CARIA, P. H. F. \& BOTACIN, P. R. Foramen caróticoclinoideo en cráneos humanos: incidencia, morfometría y sus implicaciones clínicas. Int. J. Morphol., 29(2):427-431, 2011.

RESUMEN: El foramen caróticoclinoideo es una estructura inconstante formada por la unión de la procesos clinoides anterior y medio. El objetivo de este estudio fue revisar la incidencia y la morfometría del foramen caróticoclinoideo en cráneos humanos brasileños y discutir sus implicaciones clínicas. Se utilizaron 80 cráneos humanos secos, de ambos sexos, determinando tres variables: sexo y lados derecho e izquierdo. La morfometría se realizó con un cáliper manual midiéndose el diámetro máximo del foramen. La incidencia de cráneos con al menos un foramen fue de 8,5\%. El 8,5\% de los cráneos presentó un foramen en el lado derecho y el 2,5\% en el izquierdo. El 2,5\% de los cráneos presentó un foramen bilateral y el 6,25\% un foramen unilateral. En relación al sexo, los forámenes se encontraron en el 5\% de los cráneos de hombres y el 12,5\% de los cráneos de mujeres. El diámetro máximo de esta estructura presentó en promedio, valores de 5,23 mm; 5,18 mm en el lado derecho y 5,35 mm en el izquierdo; 5,30 mm en cráneos de hombres y $5.18 \mathrm{~mm}$ en cráneos de mujeres. Las características anatómicas de este foramen deben ser consideradas debido a las implicaciones clínicas asociadas a la neurocirugía, como la eliminación del proceso clinoides y a síntomas como cefaleas producto de alteraciones en la arteria carótida interna en esta región. En conclusión, el conocimiento de esta estructura mejora el diagnóstico y tratamiento de las complicaciones clínicas relacionadas con esta variación.

PALABRAS CLAVE: Foramen; Morfometría; Arteria carótida; Fosa craneal media.

\section{REFERENCES}

Das, S.; Suri, R. \& Kapur, V. Ossification of caroticoclinoid ligament and its clinical importance in skull-based surgery. São Paulo Med. J., 125:351-3, 2007.

Dodo, Y. \& Ishida, H. Incidence of nonmetric cranial variant in several population samples from East Asia and North America. J. Anthrop. Soc. Nippon, 95:161-7, 1987.

Dolenc, V. V. A combined epi and subdural direct approach to carotidophthalmic artery aneurysms. J. Neurosurg., 5:667-72, 1985.

Donald, P. J. Surgery of the skull base. Philadelphia, Lippincott- Raven, 1998.

Erturk, M.; Kayalioglu, G. \& Govsa, F. Anatomy of the clinoidal region with special emphasis on the caroticoclinoid foramen and interclinoid osseous bridge in a recent Turkish population. Neurosurg. Rev., 27:226, 2004.

Gupta, N.; Ray, B. \& Ghosh, S. A study on anterior clinoid process and optic strut with emphasis on variations of caroticoclinoid foramen. Nep. Med. Coll. J., 7:140-4, 2005 .

Hochstetter, F. Über die Taenia interclinoidea, die Commissura alicochlearis und die Cartilago supracochlearis des menschlichen Primordialkraniums. Gegenbaurs Morph. Jahrb., 84:220-43, 1940.
Inoue, T.; Rhoton. Jr. A. L.; Theele, D. \& Barry, M. E. Surgical approaches to the cavernous sinus: a microsurgical study. Neurosurg., 6:903-32, 1990.

Kier, E. L. Embryology of the normal optic canal and its anomalies. An anatomic and roentgenographic study. Invest. Radiol., 1:346-62, 1966.

Kobayashi, S.; Kyoshima, K.; Gibo, H.; Hedge, S. A.; Takemae, T. \& Sugita, K. Carotid cave aneurysms of the internal carotid artery. J. Neurosurg., 70:216, 1989.

Lee, H. Y.; Chung, I. H. \& Choi, B. Y. Anterior clinoid process and optic strut in Koreans. Yonsei Med. J., 38:151-4, 1997.

Narolewski, R. Significance of anatomic variants of bony surroundings of the internal carotid artery and their significance for lateral surgical approaches to the cavernous sinus. Ann. Acad. Med. Stetin., 49:205-29, 2003.

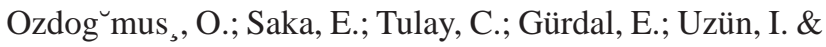
Cavdar, $\mathrm{S}$. The anatomy of the carotico-clinoid foramen and its relation with the internal carotid artery. Surg. Radiol. Anat., 25:241-6, 2003.

Reisch, R.; Vutskits, L., Filippi, R.; Patonay, L.; Fries, G. \& Perneczky, A. Topographic microsurgical anatomy of the paraclinoid carotid artery. Neurosurg Rev., 25:177-83, 2002. 
FREIRE, A. R.; ROSSI, A. C.; PRADO, F. B.; GROPPO, F. C.; CARIA, P. H. F. \& BOTACIN, P. R. Caroticoclinoid foramen in human skulls: incidence, morphometry and its clinical implications. Int. J. Morphol., 29(2):427-431, 2011.

Sekhar, L. N. \& Akin, O. Anatomical study of the cavernous sinus emphasizing operative approaches and related vascular and neural reconstruction. Neurosurg., 21:806$16,1987$.

Seoane, E.; Rhoton Jr, A.L.; Oliveira, E. Microsurgical anatomy of the dural collar (carotid collar) and rings around the clinoid segment of the internal carotid artery. Neurosurg., 42:869-86, 1998.

Sicher, H. \& Du Brul, E. L. Oral Anatomy. $6^{\text {th }}$ ed. Rio de Janeiro, Guanabara Koogan, 1977.

Standring, S. Overview of the Development of the Head and Neck Head: Skull and Mandible. In: Standring, S. (Editor). Gray's anatomy: the anatomical basis of clinical practice. New York, Elsevier, 2005.
Correspondence to:

Ms. Ana Cláudia Rossi

Postgraduate Student

Av. Limeira, 901 P.O. Box: 52

Department of Morphology

State University of Campinas

UNICAMP, 13414-903

Piracicaba, SP

BRAZIL

Email: anaclaudiarossi@fop.unicamp.br

Received: 11-11-2010

Accepted: 21-02-2011 